\title{
A long-term field study on the effects of dietary exposure of clothianidin to varroosis-weakened honey bee colonies
}

\author{
Reinhold Siede $\mathbb{C}^{1} \cdot$ Marina D. Meixner ${ }^{1} \cdot$ Maria T. Almanza ${ }^{2} \cdot$ Ralf Schöning $^{2} \cdot$ Christian Maus $^{2} \cdot$ Ralph Büchler $^{1}$
}

Accepted: 6 April 2018 / Published online: 3 May 2018

(c) The Author(s) 2018

\begin{abstract}
Clothianidin is a commonly used systemic insecticide in seed treatments. Residues of clothianidin can occur in nectar and pollen as a result of within-plant-translocation. Foraging bees can collect contaminated nectar or pollen. Concerns have been brought forward that exposure to pesticide residues might affect colonies especially if they are weakened by varroosis. However, there are few scientific studies investigating such multiple-stressor scenarios in the context of the entire colony. To close this gapa field trial with 24 colonies was set up. The study design comprised four groups of six colonies each fed with uncontaminated sugar syrup ('C0'), or syrup spiked with $10 \mu \mathrm{g} \mathrm{L}{ }^{-1}$ clothianidin ('C10'), $50 \mu \mathrm{g} \mathrm{L}{ }^{-1}$ clothianidin ('C50') or $200 \mu \mathrm{g} \mathrm{L}{ }^{-1}$ clothianidin ('C200'). C10 represented a residue concentration that may exceptionally occur and therefore a worst-case scenario, the higher dietary concentrations exceed and do not reflect fieldrealistic levels. A substantial load of 8 mites of Varroa destructor per ten gram bees in autumn was adjusted. The colonies were followed up for 328 days. The amount of brood and the strength of each colony were regularly assessed. Colony health, bee mortality, overwintering success, hive weights, and levels of in-hive residues were determined. Varroosis turned out to be the significant key factor for the endpoint colony strength. Clothianidin did not have a statistically significant impact on C0, C10 and C50 colonies. No statistical evidence was found for an interaction between varroosis andexposure to clothianidin.
\end{abstract}

Keywords Honey bee $\cdot$ Varroosis $\cdot$ Clothianidin $\cdot$ Interaction

\section{Introduction}

Clothianidin is an insecticide with a high efficacy against a broad spectrum of sucking and biting insects (Elbert et al. 2008; Uneme 2011). Even relatively small amounts of the substance are sufficient to control pests of major agricultural crops (Elbert et al. 2008; Nauen et al. 2003). Owing to its systemic properties it is suitable for seed treatment products. As clothianidin has a relatively high water solubility of $0.340 \mathrm{~g} \mathrm{~L}^{-1}$ (at $20^{\circ} \mathrm{C}, \mathrm{pH} 4-10$, (Hazardous Substances Data Bank 2005), the active ingredient of the seed coating

Electronic supplementary material The online version of this article (https://doi.org/10.1007/s10646-018-1937-1) contains supplementary material, which is available to authorized users.

Reinhold Siede

reinhold.siede@1lh.hessen.de

1 Landesbetrieb Landwirtschaft Hessen, Bieneninstitut, Erlenstr. 9, 35274 Kirchhain, Germany

2 Bayer AG, Alfred-Nobel-Str. 50, 40789 Monheim, Germany disperses to the surrounding soil moisture. The roots of the growing seedling take up the substance with the water flow. Clothianidin is easily transported within the xylem in acropetal direction to non-treated parts of the plants (Bonmatin et al. 2015; Maienfisch et al. 2001), so that insects feeding on the treated crops are exposed to the treatment. The amount taken up by the pests is sufficient to kill them during the early growth phase of the crop. Thus young seedlings that are sensitive to pest attack are protected. Treating seeds with clothianidin can help to prevent insect damage to the crops during the crucial phase of establishment. Clothianidin is used world-wide in a broad range of crops (Simon-Delso et al. 2015). In the European Union (EU), clothianidin was, for instance, applied to the seed of oilseed rape to protect the seedlings against rape flea beetle (Psylliodes chrysocephalus), cabbage root fly (Delia radicum), and diverse virus-transmitting aphids. Seed treatment with clothianidin in bee-attractive crops like oilseed rape or maize was a widespread farming practice in the EU until the restrictions in 2013 (EC 2013), and is still common in regions other than the EU. In the EU, clothianidin is currently not registered as a substance for seed application in 
oilseed rape, however, it is still in use as seed treatment for rape among others, for e.g., in Australia (https://portal. apvma.gov.au, accessed 05 December 2016), in Canada (http://www.hc-sc.gc.ca, accessed 05 December 2016), in USA, and in many other countries (Simon-Delso et al. 2015).

Honeybees might be exposed to clothianidin seed treatment in the first place through the uptake of systemic residues in nectar and pollen of seed-treated crops. This is considered the key route of exposure, although also other exposure scenarios have been documented or postulated (e.g., systemic residues in untreated plants, caused by soil residues, residues in water bodies, in guttation drops of seedlings of seed- or soil-treated plants (Blacquiere et al. 2012; Botias et al. 2015; Cresswell et al. 2012; Girolami et al. 2009; Main et al. 2014; Pohorecka et al. 2012; Schaafsma et al. 2015; Schmuck and Keppler 2003; Xu et al. 2016). The relevance of guttation as a potential exposure route for bees has been discussed intensively as residues in guttation fluids can reach toxic concentrations (Nikolakis et al. 2015; Reetz et al. 2011; Tapparo et al. 2011). However, there are no confirmed cases of bee intoxication as a result of collecting guttation fluids and experts consider the risk for the whole colony as low despite gaps in our knowledge (Pistorius et al. 2012; Thompson 2010). Another potential route of exposure was highlighted by an incident that occurred in Germany in 2008. During the drilling of clothianidin-treated maize seeds, dust from the seed coating was emitted with the planting machines' exhaust air and deposited on nearby flowers. As a consequence, foraging insects, especially bees, were exposed and intoxicated (Forster 2009; Pistorius et al. 2010). Several thousand colonies belonging to $\sim 700$ beekeepers were affected. Experiments simulating the precipitation of dust from maize drilling confirmed that there is the potential of exposure to high levels of clothianidin lethal to bees under certain conditions (Krupke et al. 2012). However, it has been shown that exposure to dust can be minimized to levels that are not toxic to bees by the use of technical solutions on the levels of seed treatment quality and planter technology (Forster et al. 2012; Nikolakis et al. 2010). Several studies report detectable amounts of clothianidin residues in nectar and pollen of seed-treated oilseed rape. The residue levels are in the order of magnitude of a few $\mu \mathrm{g}$ $\mathrm{kg}^{-1}$; typically they are far below $5 \mu \mathrm{g} \mathrm{kg}^{-1}$ (Cutler and Scott-Dupree 2007; Cutler et al. 2014; Pohorecka et al. 2012; Rolke et al. 2016b; Woodcock et al. 2017).

Clothianidin is intrinsically highly toxic to honey bees. The $\mathrm{LD}_{50}$ for oral exposure was determined as $3.8 \mathrm{ng}$ active substance per bee (Schmuck and Keppler 2003). However, the quantity of neonicotinoids collected by foragers from nectar and pollen of seed-treated crops is estimated to be far below lethal levels (Godfray et al. 2014). Therefore, an acute intoxication of the forager cannot be expected, but concerns have been raised that honey bee colonies might be damaged by a long-term exposure to small amounts of clothianidin. A number of studies have indicated that the substance may cause sublethal effects to honey bees. The compound can affect the bees' immunity, (Di Prisco et al. 2013) or their home finding capacity (Fischer et al. 2014). An alteration of the foraging behavior is reported (Schneider et al. 2012). Thiamethoxam, another neonicotinoid, which may be metabolized to clothianidin was shown to reduce locomotion of bees (Charreton et al. 2015; Williamson et al. 2014), and to affect their orientation performance (Henry et al. 2012). However, it has to be taken into consideration that many of these studies found these effects at unrealistic exposure concentrations and/or otherwise unrealistic exposure conditions. Some studies address the topic with experimental colonies under field-like conditions (Cutler et al. 2014; Pilling et al. 2013; Pohorecka et al. 2012; Sandrock et al. 2014) but the impact on colonies under farming standard conditions is less clear. However, in studies where honey bee colonies were exposed to treated crops in a field-realistic scenario (European Food Safety Authority (efsa) 2013); (Cutler and Scott-Dupree 2007; Cutler et al. 2014; Pohorecka et al. 2012; Rolke et al. 2016a; Rundlof et al. 2015), no adverse effects were found.

Generally, honey bee colonies are regularly infested by various pathogens and parasites (Genersch et al. 2010; Guzmán-Novoa et al. 2010). One of the most important is the parasitic Varroa destructor mite, which is one of the main causes of colony losses in the northern hemisphere (Neumann and Carreck 2010). Besides direct damage by mites and by viruses they are transmitting, parasitization is thought to render colonies more susceptible to diseases or to abiotic stressors as pesticides (Doublet et al. 2015). Therefore, the experiment was undertaken with the objective to address the following two questions: (a) Are honey bee colonies harmed by a long-lasting exposure to sublethal dietary concentrations of clothianidin? (b) How do colonies perform under combined stress from a substantial $V$. destructor infestation and exposure to clothianidin?

\section{Materials and methods}

\section{Experimental design and colony management}

At the beginning of June 2014, 24 experimental colonies of Apis mellifera carnica (L.) were established from shook swarms consisting of $1.5 \mathrm{~kg}$ bees. Young sister queens, mated at the mating yard "Gehlberg", Germany, were added to the swarms. The swarms were randomly distributed to four groups of six hives each. Group $\mathrm{C} 0$ was the control, which was not exposed to clothianidin. Group C10, C50, and C200 were treatment groups, orally exposed to 
clothianidin by feeding spiked syrup with nominal concentrations of $10 \mu \mathrm{g} \mathrm{L}^{-1}, \quad 50 \mu \mathrm{g} \mathrm{L}^{-1}$, and $200 \mu \mathrm{g} \mathrm{L}^{-1}$. Throughout the experiment, each syrup feeding was done with the ready-to-use formulation Ambrosia (Nordzucker AG, 38100 Braunschweig, Germany). Ambrosia consists of a mixture of glucose, fructose, and sucrose. Its nutritive value corresponds to $\sim 0.73 \mathrm{~kg}$ sucrose per $\mathrm{L}$ syrup. The swarms were encased in magazine hives with eight Zander wax foundations and two drawn Zander combs. The colonies were located at a bee yard of Landesbetrieb Landwirtschaft Hessen in Central Germany. The site was mainly surrounded by arable crop land. No major nectar sources were within a radius of $3 \mathrm{~km}$ from the experimental site during the exposure period. Colonies of each group were arranged in blocks with distances of $\sim 50 \mathrm{~m}$ between groups. From the beginning of the experiment in June 2014 to 13 August 2014 (69 DAI = days after initiation of the experiment) each colony in a treatment group was provided on four occasions with $5 \mathrm{~L}$ of spiked syrup (C10, C50, $\mathrm{C} 200$ ) or uncontaminated (C0) syrup. Feeding dates were 5 June 2014; 1 July 2014; 24 July 2014, and 13 August 2014. In September, each colony was fed twice with $5 \mathrm{~L}$ syrup without clothianidin. In October, according to the colonyspecific demands a further 2-5 L uncontaminated syrup were fed. Colonies of the $\mathrm{C} 200$ group received only two feedings of $5 \mathrm{~L}$, each following the exposure period, as they were too weak to consume the food from the feeder. Colonies that lost their queen during summer were re-queened with a sister queen from the original cohort. At the beginning of April 2015, a drone comb was added to all colonies.

Colonies were treated for Varroosis when a predefined threshold was exceeded. The threshold values were 0.2 mites $\mathrm{g}^{-1}$ bees for the shook swarms, 0.1 mites $\mathrm{g}^{-1}$ bees in mid July (14.07.; $39 \mathrm{DAI}$ ) and 0.8 mites $\mathrm{g}^{-1}$ bees in mid September (23.09.; 110 DAI). Colonies from heavily infested shook swarms were treated with $15 \%$ lactic acid on 12 June 2014. Colonies exceeding the thresholds in mid July or in mid September were treated with 2-4 strips of flumethrin (Bayvarol ${ }^{\circ}$-Bayer Vital GmbH, 51368 Leverkusen, Germany) according to colony size. In preparation for winter, all colonies were treated with $25-50 \mathrm{ml}$ coumaphos (Perizin -Bayer Vital GmbH, 51368 Leverkusen, Germany) according to colony size.

At the end of the experiment $(29.04 .15 ; 328$ DAI) all colonies were killed (details see section 'Precise determination of colony strength at the end of the study'). After that the amount of brood was measured and the number of bees counted.

\section{Exposure to clothianidin}

Clothianidin as a primary reference substance with a certified purity of $99.4 \% \mathrm{w} \mathrm{w}^{-1}$ was obtained from Bayer AG.
Stock solution I was prepared by dissolving $50 \mathrm{mg}$ clothianidin in de-mineralized water at a final volume of $0.5 \mathrm{~L}$ $\left(100 \mathrm{mg} \mathrm{L}^{-1}\right)$. A $50 \mathrm{ml}$ aliquot of stock solution I was diluted with $0.45 \mathrm{~L}$ de-mineralized water to obtain stock solution II $\left(10 \mathrm{mg} \mathrm{L}^{-1}\right)$. From stock solution I, $64 \mathrm{ml}$ were added to $0.936 \mathrm{~L}$ water, shaken for $1 \mathrm{~h}$ in the dark, and with the help of a stirrer thoroughly mixed in a barrel containing $31 \mathrm{~L}$ syrup, resulting in a concentration of $200 \mu \mathrm{g} \mathrm{L}{ }^{-1}$. The syrup containing $50 \mu \mathrm{g}$ clothianidin $\mathrm{L}^{-1}$ was prepared accordingly by adding $1 \mathrm{~L}$ of a mixture of $160 \mathrm{ml}$ of stock solution II and $0.840 \mathrm{~L}$ water. Syrup containing $10 \mu \mathrm{g}$ clothianidin $\mathrm{L}^{-1}$ was prepared by adding a mixture of $32 \mathrm{ml}$ stock solution II and $0.968 \mathrm{~L}$ water to $31 \mathrm{~L}$ syrup. For the control group $1 \mathrm{~L}$ water was added to the syrup. Fresh syrup batches were prepared a few days before each feeding date. The residue analytical laboratories of Bayer AG determined the actual concentrations with a $\mathrm{LOQ}=0.001 \mathrm{mg} \mathrm{kg}^{-1}$ and a limit of detection (LOD) of $0.0003 \mathrm{mg} \mathrm{kg}^{-1}$. Clothianidin content in the syrup of the controls (C0) were below the LOD, in the syrups of group C10, $7.4 \mu \mathrm{g} \mathrm{kg}^{-1}(=10.36 \mu \mathrm{g}$ $\left.\mathrm{L}^{-1}\right)$, of group C50, $38 \mu \mathrm{g} \mathrm{kg}^{-1}\left(=53.2 \mu \mathrm{g} \mathrm{L}^{-1}\right)$, and of group C200, $147 \mu \mathrm{g} \mathrm{kg}^{-1}\left(=205.8 \mu \mathrm{g} \mathrm{L}^{-1}\right)$. The feeding scheme is indicated above in the section entitled "Experimental Design and colony management".

\section{Residue analysis}

Samples of $10 \mathrm{~g}$ bee bread, $15 \mathrm{~g}$ stored syrup, 10 larvae, 25 adult hive bees, and 25 adult forager bees per colony were collected on DAI 69, 112, 286, and 321. To avoid risks of contamination, samples were collected with disposable gloves and single-use plastic cutlery. All samples were transported and stored in disposable plastic sample containers. Immediately after removal from the colonies, the samples were placed on dry ice. Samples were labeled with blind numbers and stored at $-20^{\circ} \mathrm{C}$. Then they were shipped in dry ice to the analytical laboratories of Bayer AG, where they were analyzed for residues of clothianidin and its metabolites TZNG and TZMU. The chemical analyses followed standard procedures (Schoening 2001).

\section{Health parameters of the colonies}

The colonies were checked for their rate of infestation with the parasitic mite $V$. destructor. Mites were counted at the beginning of the experiment, and on DAI 39, 68, 110, and 284. Sampling and counting followed the protocol of the COLOSS BEEBOOK according to the soapy water method (Dietemann et al. 2013). Adult bees were checked for infection with Nosema spp. Approximately $40 \mathrm{~g}$ of bees (corresponding to $\sim 400$ bees) were collected from a peripheral frame in July, September, and March with the intention to minimize the effect of sampling on the rather 
small-sized colonies. From each sample, 60 bees were randomly selected. The bees' abdomen were removed and macerated in plastic bags with $6 \mathrm{ml}$ water with the help of a laboratory blender (Stomacher, Seward, Lt. West Sussex, BN14 8HQ, UK). Aliquots of the resulting suspension were microscopically checked for Nosema spores, which were counted with a Bürker hemacytometer. The viral load of the colonies was analyzed at the end of the experiment according to previously published PCR-based protocols (Cox-Foster et al. 2007; Siede et al. 2008).

\section{Performance of colonies}

The strength of the colonies was estimated according to Liebefelder method on three occasions before winter (26, $68,110 \mathrm{DAI})$ and twice after overwintering (284, $320 \mathrm{DAI})$ (Imdorf et al. 1987). During estimation of the colonies the entrances were closed to prevent robbery. The number of bees and number of brood cells were assessed by three experienced staff members of Bieneninstitut Kirchhain. All three assessors were trained with the same material and verified their estimates among each other prior to the experiment to achieve equivalent results. The weight of the colonies was recorded seven times $(26,68,89,112,124$, 284, and 320 DAI) with an electronic hive-scale (Bosche, Wägetechnik, Damme, Germany, model TWI). Net weights adjusted for the weight of hive material were used for the statistical comparison of the four treatment groups.

\section{Honey bee mortality}

Adult bee mortality was measured with dead bee traps. These were two nested mesh cages. The lower wire box were $46 \mathrm{~cm}$ large, $5 \mathrm{~cm}$ high, and $10 \mathrm{~cm}$ deep and had a mesh size of $4 \mathrm{~mm}$. The overlapping upper part with the same dimensions was made from wire with a mesh size of $8 \mathrm{~mm}$. The cages were fixed in front of the hive in a manner that the complete entrances were covered by the wire boxes. All outgoing bees had to pass through the boxes. Dead bees could be collected from the lower part of the boxes. Two days after the administration of the clothianidin spiked syrup, all dead bees were removed from the traps and were counted. In the region of the study, there is no flight activity in winter. Therefore, dead bees drop out of the winter cluster and accumulate on the bottom board of the hives during winter The number of dead bees on the bottom boards were counted in February (257 DAI) before the cleansing flight and well before discarding the dead bees by nest mates. Colony mortality was defined as the removal date from the yard. C200 colonies were removed when the bees occupied not more than a single comb. During winter the colonies were checked once a week from 3 November 2014 till 26 February 2015. For inspection, the covers of the hives were lifted carefully. Colonies were removed from the yard when less than three beeways between the combs were occupied by bees.

\section{Precise determination of colony strength at the end of the study}

At the end of the trial (328 DAI), the colonies were weighed. The bees were brushed off the combs with a boxshaped device ('Kehrfix' ${ }^{\circledR}$, Carl Fritz Imkertechnik GmbH \& Co. KG, 97638 Mellrichstadt, Germany) in the early morning before flight activity. The bees were re-collected in wire mesh boxes. The boxes were placed in two-chamber bee hives, which were firmly closed up. Bees were killed by fumes from burning $20 \mathrm{~g}$ sulfur stripes in the upper chamber. The exact numbers of bees of each colony were counted manually. The area of brood in the frames of the hives was recorded with a marker to transparent sheets, scanned and the area of recorded brood measured using the open-source digital imaging software imageJ (Version 1.51n) (Abràmoff et al. 2004).

\section{Statistical analysis}

Data were tested with the procedure linear mixed models in spss v. 20. Number of bees, number of brood cells, percentage of uncapped brood and the net weights of the colonies were log-transformed. Number of $V$. destructor per $10 \mathrm{~g}$ bees were $\log (\mathrm{x}+1)$ transformed and used as covariant. An autoregressive covariance type of first order was assumed. DAI was used to define the repeated measures. DAI, treatment, and infestation with $V$. destructor as well as the interactions between treatment and DAI and between $V$. destructor and treatment were considered as fixed effects. Owing to the rapid breakdown of the colonies of the C200 group these were not considered in the statistical model. Number of bees in the dead bee traps attached to the entrance of colonies were aggregated by the area under curve (AUC) approach. analysis of variance (ANOVA) was performed with the AUC values and with the number of dead winter bees. Time periods of survival were analyzed using the Kaplan-Meier method (Bühl 2012). Survival time of colonies, which survived till the end of the experiment, was estimated as 328 days. Differences between groups were tested for significance with the log-rank test (Mantel-Cox test). Means of residues in Table 1 and the online resource 1 were calculated from detection above the limit of quantification (LOQ). Spearman two sided rank correlation coefficients were calculated between the numbers of bees at the end of the trial, the numbers of brood cells at the end of the trial, the means of the residues of clothianidin (parent compound) in the stored syrup and the mean infestation rate of $V$. destructor. For that purpose 
Table 1 Means of residues of clothianidin $\left(\mu \mathrm{g} \mathrm{kg}^{-1}\right)$

\begin{tabular}{llllll}
\hline \multirow{2}{*}{ Group } & Matrix & 69 & 112 & 286 & 321 \\
\cline { 3 - 6 } C0 & Bee bread & $<$ LOQ & $<$ LOD & $<$ LOD & $<$ LOD \\
& Forager bees & $<$ LOD & $<$ LOD & $<$ LOD & $<$ LOD \\
& Food & 1.4 & $<$ LOD & 1.7 & $<$ LOQ \\
& Hive bees & $<$ LOQ & $<$ LOD & $<$ LOD & $<$ LOD \\
& Larvae & $<$ LOD & $<$ LOD & $<$ LOD & $<$ LOD \\
C10 & Bee bread & 1.8 & $<$ LOQ & 1.6 & 1.5 \\
& Forager bees & $<$ LOD & $<$ LOD & $>$ LOQ & $<$ LOD \\
& Food & 7.3 & 3.9 & 4.2 & 4.8 \\
& Hive bees & 2.4 & $<$ LOD & $<$ LOQ & $<$ LOD \\
& Larvae & 1,7 & $<$ LOD & $<$ LOD & $<$ LOD \\
C50 & Bee bread & 8.1 & 1.9 & 2.8 & 4.7 \\
& Forager bees & 1.3 & $<$ LOD & 2.3 & $<$ LOQ \\
& Food & 27.4 & 11.2 & 22.8 & 22.7 \\
& Hive bees & 5.2 & 2.0 & 2.5 & $<$ LOQ \\
& Larvae & 1.7 & 1.2 & 1.4 & $<$ LOQ \\
\hline LO & &
\end{tabular}

$\overline{\mathrm{LOQ}}=1 \mu \mathrm{g} \mathrm{kg}^{-1}, \mathrm{LOD}=0.3 \mu \mathrm{g} \mathrm{kg}^{-1}$, means per row were calculated from values $>$ LOQ. Residues were determined in the hive matrices bee bread and food and in the three bee states (larvae, hive bees, and foragers) of controls (group $\mathrm{C} 0$ ) and the two treatment groups $(\mathrm{C} 10$ and $\mathrm{C} 50$ )

residue values of clothianidin below LOD were replaced by the half of LOD $\left(=0.15 \mu \mathrm{g} \mathrm{kg}^{-1}\right)$ and in case of values between LOD and LOQ by $0.5 \mu \mathrm{g} \mathrm{kg}^{-1}$ (US Environmental Protection Agency (EPA) 2000; US Environmental Protection Agency (EPA) 2006).

\section{Results}

\section{Residues}

Clothianidin residues were found in bee bread samples of the C10 and C50 group (see Table 1 and additional data given in the online resource). The mean clothianidin residue in the $\mathrm{C} 10$ bee bread sample was $1.8 \mu \mathrm{g} \mathrm{kg}^{-1}$ at $69 \mathrm{DAI},<$ LOQ at $112 \mathrm{DAI}, 1.6 \mu \mathrm{g} \mathrm{kg}^{-1}$ at $286 \mathrm{DAI}$, and $1.5 \mu \mathrm{g} \mathrm{kg}^{-1}$ at 321 DAI. Clothianidin residues in bee bread of the C50 samples ranged between $1.9 \mu \mathrm{g} \mathrm{kg}^{-1}$ and $8.1 \mu \mathrm{g} \mathrm{kg}^{-1}$. Only one sample of $\mathrm{C} 0$ bee bread was contaminated with a residue content below LOQ on 69 DAI. C200 colonies did not collect pollen. Therefore, residue analysis of bee bread of C200 colonies was not possible. In mid-August at 69 DAI stored syrup was contaminated with $1.4 \mu \mathrm{g} \mathrm{kg}^{-1}$ for C0 colonies, $7.3 \mu \mathrm{g} \mathrm{kg}^{-1}$ for $\mathrm{C} 10$ colonies, $27.4 \mu \mathrm{g} \mathrm{kg}^{-1}$ for C50 colonies and $108.6 \mu \mathrm{g} \mathrm{kg}^{-1}$ for the $\mathrm{C} 200$ group. The contents decreased in autumn (112 DAI, C0: <LOD; C10: $3.9 \mu \mathrm{g} \mu \mathrm{g} \mathrm{kg}^{-1}$, C50: $11.2 \mu \mathrm{g} \mathrm{kg}^{-1}$ ) and after winter leveled

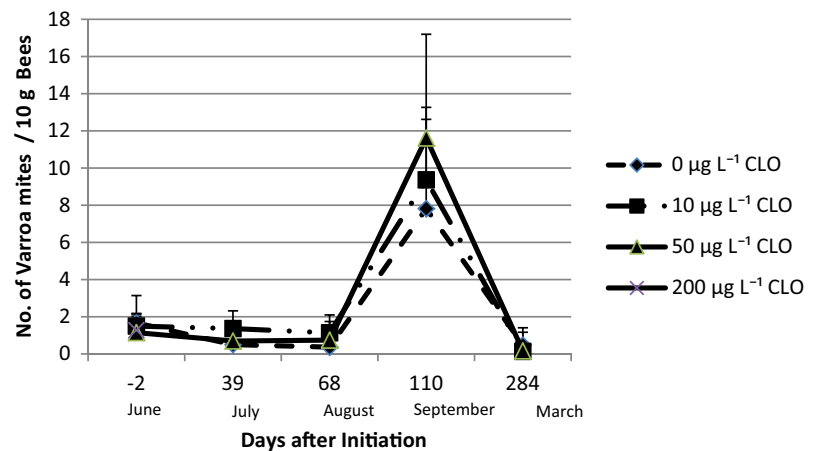

Fig. 1 Varroa destructor infestation rate as a function of time and the exposure to clothianidin. error bars: $+1 \mathrm{SD}$; For group C200 there is only one data point at -2 DAI as these colonies dwindled rapidly. $\mathrm{CLO}=$ clothianidin

off at group characteristic concentrations ( $C 0: \leq 1.7 \mu \mathrm{g} \mathrm{kg}^{-1}$, $\mathrm{C} 10 \leq 4.8 \mu \mathrm{g} \mathrm{kg}^{-1}$, and $\mathrm{C} 50 \leq 22.8 \mu \mathrm{g} \mathrm{kg}^{-1}$ ). The highest concentrations occurred in stored syrup with $22.9 \mu \mathrm{g} \mathrm{kg}^{-1}$, which is the mean across the four sampling dates and all groups. The other analyzed matrices contained much lower residues of clothianidin. Hive bees were loaded with a mean of $7.1 \mu \mathrm{g} \mathrm{kg}^{-1}$, larvae with a mean $2.7 \mu \mathrm{g} \mathrm{kg}^{-1}$, and forager bees with a mean of $2.1 \mu \mathrm{g} \mathrm{kg}^{-1}$.

Quantifiable amounts of the metabolite TZNG were found in 14 samples out of 324 analyzed samples where 8 samples belonged to group $\mathrm{C} 200$ and 6 samples belonged to group C50. From the 14 samples with detects of TZNG, two were hive bees and 12 samples were stored syrup samples. Out of the 324 analyzed samples, the metabolite TZMU was quantifiable in 9 samples only. Five of them belonged to group $\mathrm{C} 200$ in the matrices hive bees (four detections, mean: $2.28 \mu \mathrm{g} \mathrm{kg}^{-1}$; SD:2.32 $\mu \mathrm{g} \mathrm{kg}^{-1}$ ) and stored syrup (one detection, $4.85 \mu \mathrm{g} \mathrm{kg}^{-1}$ ) and four to group C50 in stored syrup (mean: $1075 \mu \mathrm{g} \mathrm{kg}^{-1}$; $\mathrm{SD}=0.15 \mu \mathrm{g} \mathrm{kg}^{-1}$ ).

\section{Loads with pest and pathogens}

All colonies were substantially infested with $V$. destructor (see Fig. 1). At the beginning the mean loads of the artificial swarms were 1.67 mites $/ 10 \mathrm{~g}$ bees for the $\mathrm{C} 0$ group, 1.5 mites/10 g bees for the $\mathrm{C} 10$ group, 1.14 mites/10 $\mathrm{g}$ bees for the C50 group, and 1.28 mites $/ 10 \mathrm{~g}$ bees for the C200 group. Differences were not significant $(p=0.818$, ANOVA data $\log (\mathrm{x}+1)$ transformed $)$. As the colonies were treated for Varroa only when predefined thresholds of infestation were exceeded (see material and methods) the infestation rates during the summer remained more or less constant. The respective values for the important period of winter bee production in July were 0.5 mites $/ 10 \mathrm{~g}$ bees for $\mathrm{C} 0,1.37$ for $\mathrm{C} 10$ and 0.70 for $\mathrm{C} 50$. There are no values for the $\mathrm{C} 200$ colonies as they were already collapsed at that time. The respective values in August were 0.37, 1.14, and 
Table 2 Mean Nosema spp. spore loads and occurrence of viruses in $\mathrm{C} 0, \mathrm{C} 10$, and $\mathrm{C} 50$ colonies

\begin{tabular}{|c|c|c|c|c|c|}
\hline \multirow[b]{2}{*}{ Group } & \multicolumn{3}{|c|}{ No. of spores of Nosema spp. } & \multicolumn{2}{|c|}{$\begin{array}{l}\text { Viruses (number of } \\
\text { positive detections) }\end{array}$} \\
\hline & $\begin{array}{l}\text { 14.07.14 } \\
\text { 39 DAI }\end{array}$ & $\begin{array}{l}23.09 .14 \\
110 \mathrm{DAI}\end{array}$ & $\begin{array}{l}16.03 .15 \\
284 \text { DAI }\end{array}$ & $\begin{array}{l}\text { ABPV } \\
328 \text { DAI }\end{array}$ & $\begin{array}{l}\text { DWV } \\
328 \text { DAI }\end{array}$ \\
\hline $\mathrm{C} 0$ & 0 & 56,667 & 10,000 & 0 (out of 5 ) & 3 (out of 5 ) \\
\hline $\mathrm{C} 10$ & 48,333 & 0 & 0 & 0 (out of 3 ) & 2 (out of 3 ) \\
\hline $\mathrm{C} 50$ & 0 & 463,333 & 0 & 0 (out of 5 ) & 3 (out of 5 ) \\
\hline
\end{tabular}

ABPV: Acute Bee Paralysis Virus; DWV: Deformed Wing Virus. Group C200 is not included because C200 colonies were very weak or died prior to the assessment time

0.74 mites $/ 10 \mathrm{~g}$ bees. In September, (110 DAI) there was a sharp increase to 7.82 mites $/ 10 \mathrm{~g}$ bees for the $\mathrm{C} 0$ group, 9.37 mites $/ 10 \mathrm{~g}$ bees for the $\mathrm{C} 10$ group, and 11.62 mites/ $10 \mathrm{~g}$ bees for the C50 group, The means of infestation in number mites per $10 \mathrm{~g}$ bees calculated over all five sampling dates were 2.22 for $\mathrm{C} 0$ colonies $(N=29, \mathrm{SD}=3.82)$, 2.99 for the $\mathrm{C} 10$ colonies $(N=27 ; \mathrm{SD}=4.95)$ and 2.97 for the $\mathrm{C} 50$ colonies $(N=29, \mathrm{SD}=6.11)$. For the $\mathrm{C} 200$ colonies, no data could be measured due to the rapid collapse of the colonies following exposure to the treatment. After the application of coumaphos in winter a mean of 186 mites were collected from the $\mathrm{C} 0$ colonies. $(\mathrm{SD}=185 ; N=6)$. From the $\mathrm{C} 10$ colonies, 700 mites dropped $(\mathrm{SD}=637, N=$ 5) vs. 319 mites from $\mathrm{C} 50$ colonies $(\mathrm{SD}=417, N=5)$. There was no statistical difference in the number of Varroa mites collected in each of the treatment groups $(p=0.428$, Kruskal-Wallis Test). At the end of the experiment the mite-vectored acute bee paralysis virus was not detected in the analyzed samples. Deformed wing virus was found in eight out of 13 colonies (Table 2). Nosema spore levels were well below those that would result in beekeeper concern (Table 2).

\section{Bee mortality}

The number of bees in dead bee traps were determined 2 days after feeding at 2 DAI, 28 DAI, 51 DAI, and 71 DAI with an overall mean of 28 dead bees for colonies of the $\mathrm{C} 0$ group, 37 for $\mathrm{C} 10$, and 30 for C50. Differences between the groups were not statistically significant $(p=0.68$, ANOVA of the AUC values). Colonies of the C200 group had only three dead bees in the trap (mean of 2 DAI, 28 DAI, and 51 DAI). The majority of the dead bees of $\mathrm{C} 200$ colonies were found inside the hive. The numbers of dead bees collected in February from the bottom boards of the hives were not statistically different between groups ( $p=0.236$, ANOVA). On the average $\mathrm{C} 0$ colonies had 1720 dead bees $(N=6, \mathrm{SD}$ $=666), \mathrm{C} 10$ colonies $2076(N=3, \mathrm{SD}=1309)$ and $\mathrm{C} 50$
Table 3 Period of survival of the test colonies in (d), Kaplan-Meyer analysis, differences between group $\mathrm{C} 0, \mathrm{C} 10$, and $\mathrm{C} 50$ were not significant (log-rang test, Mantel-Cox test: $p=0.368$ )

\begin{tabular}{lllll}
\hline Group & Mean estimate & St. error & \multicolumn{2}{l}{$95 \%$ confidence interval } \\
\cline { 4 - 5 } & & & Lower bound & Upper bound \\
\hline C0 & 316,167 & 10,802 & 294,994 & 337,339 \\
C10 & 280,833 & 21,483 & 238,726 & 322,940 \\
C50 & 304,500 & 21,452 & 262,453 & 346,547 \\
C200 & 54,667 & 8433 & 38,138 & 71,195 \\
Overall & 239,042 & 23,399 & 193,180 & 284,903 \\
\hline
\end{tabular}

Table 4 Number of colonies $(N)$ that were estimated on each date of assessment

\begin{tabular}{lllllll}
\hline Group & 01 & 12 & 23 & 16 & 21 & 29 \\
& July & August & September & March & April & April \\
& 14 & 14 & 14 & 15 & 15 & 15 \\
DAI & 26 & 68 & 110 & 284 & 320 & 328 \\
\hline C0 & 6 & 6 & 6 & 5 & 5 & 5 \\
C10 & 6 & 6 & 6 & 3 & 3 & 3 \\
C50 & 6 & 6 & 6 & 5 & 5 & 5 \\
C200 & 5 & 2 & 0 & 0 & 0 & 0 \\
\hline
\end{tabular}

DAI: days after initiation

Each group started with six colonies at the beginning of the experiment. In case of $N<6$, colonies were so weak that they had been removed from experimental yard to avoid robbery

colonies had 1110 dead bees $(N=5, \mathrm{SD}=469)$ on the bottom boards.

\section{Survival of the colonies}

The colonies of the C200 group that were exposed to an acutely toxic dietary concentration of clothianidin lost the largest proportion of their bees within 2 months. Estimated mean period of colony survival was 316 days for $\mathrm{C} 0$, 281 days for C10, 304 days for C50, and 55 days for C200. (see Table 3). Differences of the survival period between $\mathrm{C} 0, \mathrm{C} 10$, and $\mathrm{C} 50$ were not statistically significant $(p=$ 0.368; Mantel-Cox test). During the winter $1 \mathrm{C} 0,3 \mathrm{C} 10$, and 1 C50 colony (colonies) did not survive. No obvious effects on queen survival were observed. Only one C10 colony had lost its queen, which was compensated by requeening. Table 4

\section{Parameters of colony performance and health}

The parameters colony strength (number of adult bees per colony), number of brood cells, and colony weight were measured. Colonies of the $\mathrm{C} 200$ group suffered from a massive loss of bees following exposure to the treatment. 


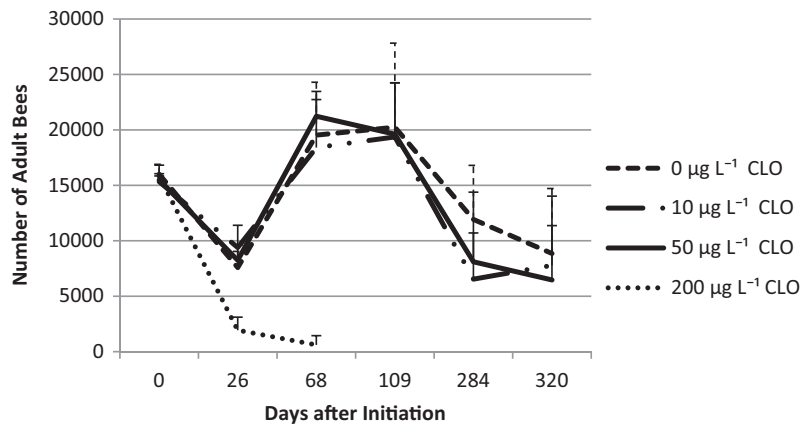

Fig. 2 Numbers of adult bees per colony (colony strength) assessed according to the Liebefeld method as a function of time and the exposure to clothianidin; error bars: +1 standard deviation (SD). At DAI 0 the numbers of bees were converted from the bee weight of the shook swarms with the assumption that $1 \mathrm{~kg}$ bees corresponds to 10,000 bees. During the period of DAI 68 to DAI 320 there was no significant difference between the groups $\mathrm{C} 0, \mathrm{C} 10$, and $\mathrm{C} 50$ ( $p=$ 0.708). $\mathrm{CLO}=$ clothianidin

The other treatment groups were not significantly affected by exposure to clothianidin at the given concentrations based on the parameters measured. The strength of the colonies was not influenced by the exposure to clothianidin ( $p=0.536$; see Fig. 2). On average, C0 colonies had 14,246 bees $\left(N_{\mathrm{obs}}=\right.$ number of observations $\left.=26 ; \mathrm{SD}=7247\right) \mathrm{vs}$. 13,582 bees of the $\mathrm{C} 10$ colonies $\left(N_{\mathrm{obs}}=24 ; \mathrm{SD}=6837\right)$ and 13,123 bees of the C50 colonies $\left(N_{\text {obs }}=28, \mathrm{SD}=\right.$ $7502)$ and 1817 bees of the $\mathrm{C} 200$ colonies $\left(N_{\mathrm{obs}}=6\right.$; $\mathrm{SD}=$ 679). Interactions between exposure to clothianidin and time were not significant $(p=0.163)$. The infestation with $V$. destructor was a significant factor related to colony strength $(p=0.004)$. Interaction between $V$. destructor and treatment was not significant $(p=0.463)$. Exposure to clothianidin had no significant influence to the numbers of brood cells (Fig. 3, $p=0.865$ ). No significant interactions were found between time and exposure $(p=0.700) . V$. destructor played a significant role for the production of brood cells $(p<0.001)$. The interaction between $V$. destructor and treatment was not significant for brood $(p=$ $0.977)$. The mean values for brood cell numbers were 14,869 in the $\mathrm{C} 0$ colonies $(N=26 ; \mathrm{SD}=7089)$ vs. 17,201 in the $\mathrm{C} 10$ colonies $(N=24, \mathrm{SD}=9136)$ and 14,845 in the C50 colonies $(N=28, \mathrm{SD}=8119)$ and 1150 in the $\mathrm{C} 200$ colonies $(N=6, \mathrm{SD}=679)$. The percentage of uncapped brood of $\mathrm{C} 0, \mathrm{C} 10$, and $\mathrm{C} 50$ was not dependent on the treatment $(p=0.797)$, nor on the interactions of time and treatment $(p=0.390)$. The means were $39 \%(\mathrm{C} 0, N=27$, $\mathrm{SD}=12.225), 37 \%(\mathrm{C} 10 ; N=24 ; \mathrm{SD}=16.4), 36 \%(\mathrm{C} 50$; $N=28 ; \mathrm{SD}=14.6)$ and $85 \%(\mathrm{C} 200, N=6 ; \mathrm{SD}=14.6)$. With respect to the net weights of the colonies, there was a trend of a clothianidin induced increase $(p=0.089)$. Interactions between treatment and time were not significant ( $p$ $=0.711$ ) but again, $V$. destructor had a significant negative impact on colony weight $(p=0.005)$. Interactions between

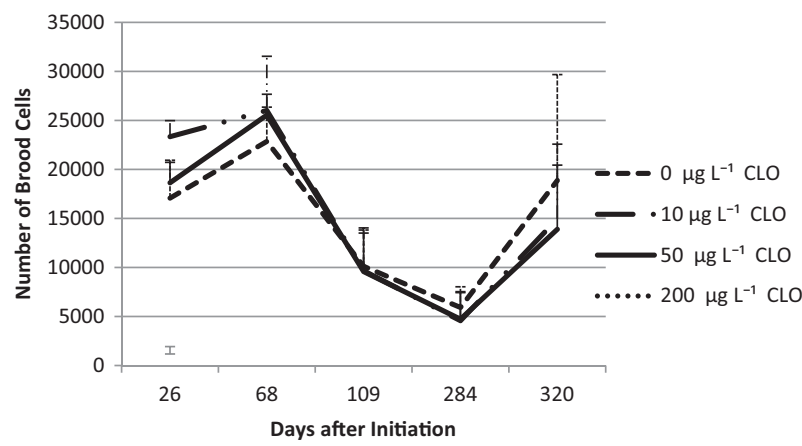

Fig. 3 Number of brood cells per colony as a function of time and the exposure to clothianidin; error bars: $+1 \mathrm{SD}$. Treatment groups $\mathrm{C} 10$ and C50 were not significantly different from group C0 $(p=0.593)$. $\mathrm{CLO}=$ clothianidin

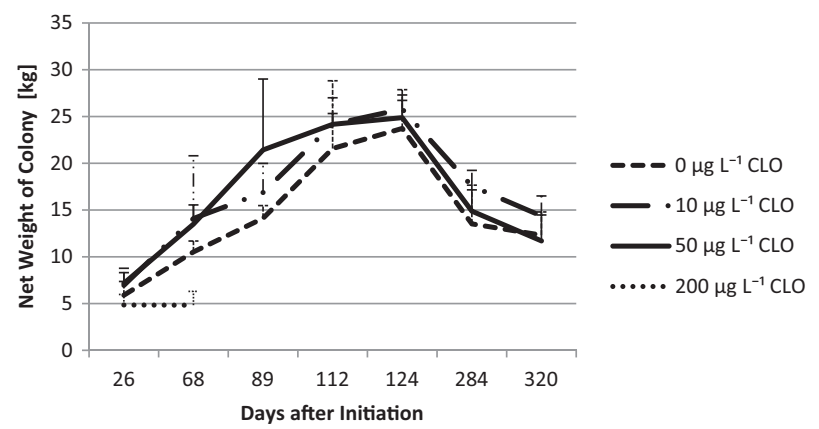

Fig. 4 Net weight of the colonies as a function of time and the exposure to clothianidin; error bars: $+1 \mathrm{SD}$, Weights were corrected for addition or removal of the weights of hive material. CLO = clothianidin

$V$. destructor and treatment were not significant $(p=0.402)$. Colonies of the $\mathrm{C} 0$ group $(14.81 \mathrm{~kg}, N=38 ; \mathrm{SD}=656)$ were lighter than the exposed colonies (see Fig. 4). The respective mean values were $17.312 \mathrm{~kg}$ for $\mathrm{C} 10$ colonies $(N$ $=36 ; \mathrm{SD}=7.17), 17.65 \mathrm{~kg}$ for the $\mathrm{C} 50$ colonies $(N=40$; $\mathrm{SD}=7.71)$ and $4.84 \mathrm{~kg}$ for $\mathrm{C} 200$ colonies $(N=10, \mathrm{SD}=$ 1.19).

\section{Colony strength at the end of the experiment}

The surviving colonies of all treatment groups (five $\mathrm{C} 0$ colonies, three $\mathrm{C} 10$ colonies, and five $\mathrm{C} 50$ colonies) were killed at 328 DAI. The mean values were 17,645 bees and 23,386 brood cells for C0 colonies, $(N=5)$ vs. 13,141 bees and 26,015 brood cells for $\mathrm{C} 10$ colonies $(N=3)$, and 12,615 bees and 19,654 brood cells for C50 colonies $(N=$ 5) (see Table 5). Both, the smallest colony with 4,950 bees and the largest colony with 28,737 bees belonged to the C50 group. The differences between the groups were not statistically significant $(p=0.601)$. A significant correlation was found between the colony strength at the end of the experiment and the infestation rate of $V$. destructor (see Table $6, \quad$ Rho $=-0.665 ; \quad p=0.013, \quad$ Spearman rang 
Table 5 Counted numbers of adult bees and brood cells per colony at the end of the trial in April 2015, 328 days after the set up of the experiment (in parentheses: $N$ : number of colonies); differences between the groups were not significant (ANOVA; SD: standard deviation)

\begin{tabular}{lllll}
\hline & C0 (5) & C10 (3) & C50 (5) & $p$ \\
\hline Bees & 17,645 & 13,141 & 12,615 & 0.601 \\
SD & 6320 & 8457 & 9659 & \\
Brood & 23,386 & 26,015 & 19,654 & 0.755 \\
SD & 14,221 & 13,254 & 7856 & \\
\hline
\end{tabular}

Table 6 Spearman rank correlation of the variables $V$. destructor (mean infestation rate), residues of clothianidin in the stored syrup (65 measurements), and the amount of bees and of brood cells at the end of the experiment after sacrificing the colonies

\begin{tabular}{lllll}
\hline & Bees & Brood & V. destructor & Residues $^{\mathrm{b}}$ \\
\hline Bees & 1 & $\mathbf{0 . 6 2 1} *$ & $-\mathbf{0 . 6 6 5 *}$ & 0.038 \\
& & 0.024 & 0.013 & 0.901 \\
& 13 & 13 & 13 \\
Brood & 1 & -0.297 & 0.176 \\
& & 0.325 & 0.566 \\
& & 13 & 13 \\
V. destructor & & 1 & -0.046 \\
& & & & 0.791
\end{tabular}

18

Residues

1

${ }^{\mathrm{a}}$ Mean rate of infestation

${ }^{b}$ Mean residues of the parent compound in stored food

Each line contains the Spearman's rank correlation coefficient, its significance level and the sample size

Statistically significant correlations $(\mathrm{p}<0.05)$ are indicated by bold letters

correlation). Residues levels were not linked to any of the parameters $(p<0.565$, Table 6 , Spearman rank correlation). The C0 colonies had 4943 drone brood cells $(\mathrm{SD}=3163)$. C10 colonies had 3906 drone cells $(\mathrm{SD}=2818)$ and C50 colonies 3610 drone cells $(\mathrm{SD}=2517$, all values are means). The differences were not statistically significant ( $p$ $=0.752$ ).

\section{Discussion}

Honey bee colonies were fed with clothianidincontaminated sugar syrup. The nominal concentrations were $0 \mu \mathrm{g} \mathrm{L}^{-1}, 10 \mu \mathrm{g} \mathrm{L}^{-1} 50 \mu \mathrm{g} \mathrm{L}^{-1}$, and $200 \mu \mathrm{g} \mathrm{L}^{-1}$. The colonies were followed until DAI 328. As expected, the C200 colonies, which were exposed to the unrealistically high concentration of $200 \mu \mathrm{g} \mathrm{L}^{-1}$, dwindled within 2 months. The survival rates were $85 \%$ for the $\mathrm{C} 0$ group,
$85 \%$ for the C50 group, and $50 \%$ for the $\mathrm{C} 10$ colonies. Exposed colonies had more clothianidin residues in in-hive matrices, more Varroa mites and tended to have a reduced colony strength, less brood, and a shorter mean survival period than the control colonies. However, differences were not statistically significant, and none of the endpoints was dependent on exposure. Moreover, there was no clear doseresponse relationship given for any differences between the groups. Significant variables were time and infestation with $V$. destructor. Interactions between time and treatment were never statistically significant indicating that statistically there was no delayed effect of the treatment on the endpoints. $V$. destructor infestation significantly influenced the colony strength, number of brood cells and colony weight. As the interactions between $V$. destructor and the treatment were not significant we did not observe indications for synergism between both stressors. At the end of April in the year following exposure to the test substance, colony strengths were determined precisely. At that time exposed colonies had $\sim 26 \%$ (C10) or $29 \%$ (C50) less bees than C0 colonies, but again, the differences were not statistically significant. In absolute numbers, $\mathrm{C} 10$ colonies had a mean of 4505 bees and C50 colonies had 5030 bees less than control colonies. Correlative evidence was found for a significant effect of $V$. destructor but not for an effect of the residues of clothianidin.

Low statistical power is a common phenomenon of field assays with honey bee colonies (Cresswell 2011; Pilling et al. 2013). The number of hives, which would be required to conduct an optimal statistical evaluation, can amount to several hundred of hives, especially if the study deals with low effect sizes (EFSA Panel on Plant Protection Products and their Residues (PPR) 2012). These numbers are likely to exceed the number of colonies, which can technically and logistically be handled in the field. Current valid regulatory guidelines demand for three replicates, only, with the aim to allow statistical testing (OEPP/EPPO 2010). However, this has been criticized as such a low number of replicates does not allow for the detection of small effects where a 'small effect' has been defined as an increase of daily forager losses about the factor 2 compared with untreated controls (EFSA Panel on Plant Protection Products and their Residues (PPR) 2012). Regarding our study, inferential statistics was performed but it cannot be excluded, that possible effects of the insecticide remained unnoticed due to the relatively low sample size. A recent large correlative study of thousands of fields cultivated with imidacloprid treated oilseed rape claimed to work out subtle effects of pesticides on bee colonies, given the availability of huge numbers of data sets (Budge et al. 2015); however, unfortunately the study failed to investigate a larger set of factors known to likewise influence bee health. 
Without doubt, the infestation with $V$. destructor was a significant driver for reduced colony performance in general. In our study, there was a significant correlation between the level of parasitization and the strength of colonies at the end of the experiment. During the period of the experiment, $V$. destructor was a significant factor for the parameters colony strength, number of brood cells, net weights of the colonies and proportion of uncapped brood. This study intended to investigate a possible influence of clothianidin on colonies, which are affected by $V$. destructor, as devitalization of colonies by varroosis is a common situation in real beekeeping. Therefore, we deliberately opted for a soft mite control concept. Substantial numbers of $V$ destructor dropped from the colonies after the winter treatment, which demonstrated that the colonies were really infested with $V$. destructor.

This study simulated a worst case scenario. Exposure levels of clothianidin were at the high end, even in the lower exposure level group, or even strongly exaggerated. Bees were exposed to contaminated food for a long period of time. Both, the levels of residues as well as the long duration exceeded a realistic exposure in the field. In nectar/ pollen of seed-treated oilseed rape clothianidin residues significantly below $10 \mu \mathrm{g} \mathrm{kg}^{-1}$ are typically found (Blacquiere et al. 2012; Rolke et al. 2016b; Schmuck and Keppler 2003). As colonies usually do not forage exclusively on one individual crop, a dilution of contaminated nectar can furthermore be assumed. In reality the time of exposure would also be drastically shorter, as at the end of the season the beekeeper normally removes the honey from the hive and replaces it by syrup for overwintering. In this study, no food was removed nor a major nectar flow diluted the clothianidin-contaminated food of the experimental colonies. The recovery rates (see Table 1) suggest that the dilution factor was not higher than two, whereas metabolization and clearance of clothianidin are not taken into account. The data prove the very high exposure of the colonies. Interestingly also on the level of the individual bees the exposure exceeded even the values of the laboratory derived oral LD50 values of $3.8 \mathrm{ng}$ (Schmuck and Keppler 2003). Assuming a daily sugar uptake of $18 \mathrm{mg}$ per bee $(=24.7 \mu$ l of syrup), (Blacquière and van der Steen 2017), a life expectancy of 28 days and a real mean clothianidin content of $5 \mu \mathrm{g} \mathrm{kg}^{-1}\left(=0.007 \mathrm{ng} \mathrm{LL}^{-1} ; \mathrm{C} 10\right), 21$ $\mu \mathrm{g} \mathrm{kg}^{-1}$ (=0.029 $\left.\mathrm{ng} \mu \mathrm{L}^{-1} ; \mathrm{C} 50\right)$, and $108 \mu \mathrm{g} \mathrm{kg}^{-1}(=0.151$ ng $\mu \mathrm{L}^{-1}$; C200, see Table 1) each bee was exposed to a total dose of $4.88 \mathrm{ng},(\mathrm{C} 10), 20.32 \mathrm{ng}$ (C50), and $104.39 \mathrm{ng}$ (C200). Although all of them are above the LD50 there was no elevated mortality except for C200 colonies. A similar phenomenom had been observed for the neonicotinoid imidacloprid. (Blacquière and van der Steen 2017) explained that phenomenon by detoxification or elimination of the substance at a rate of $2.2 \mathrm{ng}$ per $24 \mathrm{~h}$ (Cresswell et al.
2014). LD50 are determined by exposing bees to the doses at a single blow. As the bees of the field study were exposed to high amounts of clothianidin continuously their detoxification system has more time to get off the substances. Supposing that the clothianidin elimination is similar to the imidacloprid clearance each bee has the potential to eliminate a total of $61.6 \mathrm{ng}$, which is above the doses absorbed by the bees.

The no observable effect concentration (NOEC) of clothianidin for individual worker bees was determined in a 10 days lasting feeding study in the laboratory. A NOEC of $10 \mu \mathrm{g} \mathrm{L}^{-1}$ or $8.13 \mu \mathrm{g} \mathrm{kg}^{-1}$ was found (European Food Safety Authority (efsa) 2013). Thus, short- or mid-term effects were unlikely to be seen in the C10 colonies, and as no significant effect for the whole period of the experiment was observed, it can be concluded that there was likewise no cumulative effects. $\mathrm{C} 50$ colonies were confronted with a nominal dietary concentration of $50 \mu \mathrm{g} \mathrm{L}^{-1}$ and a verified concentration of approx. $20 \mu \mathrm{g} \mathrm{kg}^{-1}$. No indications neither for short-term nor cumulative effects were observed. Modeling time effects of imidacloprid, another neonicotinoid, on honey bees, predicted a marked increase of the sensitivity with time (Rondeau et al. 2014). The authors of this study hypothesized that despite low exposure concentrations there might be a huge biological damage, as neonicotinoid substances allegedly would bind irreversibly to neural receptors. Our data do not support such assumptions for clothianidin. At least under field conditions, we do not see evidence for a time-enhanced effect of clothianidin at the colony level.

Colonies of eusocial insects have mechanisms to compensate for disturbances by external factors. A reduced lifespan of specific individuals, which might have been more exposed to a toxicant could be out-balanced by an increase of life expectancy of other individuals. If higher clothianidin concentrations affected the success of brood rearing it could be compensated by an increase of the lifespan of the adults or by an increase of the investment in brood. The quotients of adult bees to bee brood were 1.2 adult bees per brood cell for $\mathrm{C} 0,1.1$. for $\mathrm{C} 10$, and 1.1 . for C50 colonies. However, differences between the control and the $\mathrm{C} 10$ and C50 colonies were not statistically significant neither for the parameters number adult bees nor number brood cells nor for the quotient between both parameters. There is no evidence for a clothianidin induced effect nor for a compensative reaction. If colonies react in that matter the capacity for compensation of the strongly overexposed C200 colonies was obviously exhausted.

The findings of our study are in agreement with quite a large body of field assays. Most of the experimental studies did not find significant effects of clothianidin residues in nectar or pollen from seed treatment (Cutler and ScottDupree 2007; Cutler et al. 2014; Rolke et al. 2016a; 
Rundlof et al. 2015) nor from treatment with thiamethoxam, a neonicotinoid, which can be metabolized to clothianidin (Pilling et al. 2013). Colony-feeding experiments are reported with small colonies, which were not affected by high concentrations up to $20 \mu \mathrm{g}$ clothianidin $\mathrm{kg}^{-1}$ (Schmuck and Keppler 2003). To our knowledge there is only one investigation that reports effects of clothianidin on honey bee colonies in the field (Sandrock et al. 2014). The authors of this study exposed bees by in-hive feeding of contaminated pollen pasties. Effects on the number of bees were observed at two points of time, shortly after application of the substances, and a delayed effect was observed a year after the application of the compounds. However, in contrast to the studies cited before, the exposure of bee colonies in Sandrock et al. (2014) was not reflecting fieldrealistic conditions, as colonies were artificially fed instead of foraging on treated crops. No evidence of adverse effects of neonicotinoid seed treatment is reported from monitoring studies (Fairbrother et al. 2014) and reviewed by (Schmuck and Lewis 2016). However, a correlative study claimed to have detected an increased risk for honey bee colonies to die in correlation with exposure to residues originating from seed treatment with imidacloprid (Budge et al. 2015). Further investigations may help to better judge the validity of such correlative approaches, which exclusively focus on one single potential causative factor.

Residues of the parent compound clothianidin and of its metabolites TZNG and TZMU were analyzed in stored syrup, in forager bees, hive bees, bee bread, and larvae. No accumulation was observed. During winter, residues in the stored syrup decreased to the half of the initial concentrations, but did not completely disappear. After winter, a maximum concentration of $28.8 \mu \mathrm{g} \mathrm{kg}^{-1}$ was found in stored syrup of C50 colonies, which, however, originated from an unrealistically high exposure level. On average the NOEC level of $10 \mu \mathrm{g} \mathrm{L}^{-1}$ syrup respective of $8.13 \mu \mathrm{g} \mathrm{kg}^{-1}$ (European Food Safety Authority (efsa) 2013) (see Table 1) was not exceeded in group $\mathrm{C} 0$ and $\mathrm{C} 10$. A critical point is the presence of residues of clothianidin $\left(<1.7 \mu \mathrm{g} \mathrm{kg}^{-1}\right)$ in syrup of the control $\mathrm{C} 0$ colonies. The origin of these residues is unclear. Possibly robbing bees could have taken away clothianidin-contaminated food from colonies of group $\mathrm{C} 10$ or $\mathrm{C} 50$ or $\mathrm{C} 200$. A larger distance between the colonies could have reduced the problem of robbery. We did not opt for a wide spacing of the experimental colonies. It was intended to perform the study on a single experimental site to reduce the impact of environmental factors on the experiment. Nevertheless, we think that the findings of the study are reliable. The samples of stored food of the $\mathrm{C} 0$ colonies had low level of residues or even levels below LOQ (16 out of 23 samples; see online resource). Comparing the different matrices stored syrup contained the highest concentrations of residues (mean $22.9 \mu \mathrm{g} \mathrm{kg}^{-1}$ ).
Concentrations of residues and metabolites in living adult bees were low with a mean of $2.1 \mu \mathrm{g} \mathrm{kg}^{-1}$ for foragers and $7.1 \mathrm{~kg}^{-1}$ for hive bees. Low concentrations were measured in larvae (mean $2.7 \mu \mathrm{g} \mathrm{kg}^{-1}$ ). We can therefore conclude that the colonies were in fact exposed during the whole duration of the experiment. Regarding this point the experimental design was suitable to reveal possible effects. Obviously, no bee product acts as sink for clothianidin or its metabolites. There seems to be a dynamic equilibrium between the input of the substance, its metabolization and the elimination of the pesticide.

Acknowledgements The project was supported by funds of the Federal Ministry of Food and Agriculture (BMEL) based on a decision of the Parliament of the Federal Republic of Germany via the Federal Office for Agriculture and Food (BLE) under the innovation support programme.

Funding The study was funded by the Federal Ministry of Food and Agriculture (BMEL) based on a decision of the Parliament of the Federal Republic of Germany via the Federal Office for Agriculture and Food (BLE) under the innovation support programme (grant number 313-06.01-28-1-71.002-10).

Conflict of interest The authors Maria T. Almanza, Ralf Schöning and Christian Maus work for the company Bayer AG. The remaining authors declare that they have no conflict of interest.

Ethical approval This article does not contain any studies with human participants performed by any of the authors. All applicable international, national, and/or institutional guidelines for the care and use of animals were followed.

Open Access This article is distributed under the terms of the Creative Commons Attribution 4.0 International License (http://crea tivecommons.org/licenses/by/4.0/), which permits use, duplication, adaptation, distribution, and reproduction in any medium or format, as long as you give appropriate credit to the original author(s) and the source, provide a link to the Creative Commons license, and indicate if changes were made.

\section{References}

Abràmoff MD, Magalhães PJ, Ram SJ (2004) Image processing with ImageJ. Biophotonics Int 11:36-42

Blacquiere T, Smagghe G, Van Gestel CA, Mommaerts V (2012) Neonicotinoids in bees: a review on concentrations, side-effects and risk assessment. Ecotoxicology 21:973-992

Blacquière T, van der Steen JJ (2017) Three years of banning neonicotinoid insecticides based on sub-lethal effects: can we expect to see effects on bees? Pest Manag Sci 73:1299-1304

Bonmatin JM, Giorio C, Girolami V, Goulson D, Kreutzweiser DP, Krupke C, Liess M, Long E, Marzaro M, Mitchell EA, Noome DA, Simon-Delso N, Tapparo A (2015) Environmental fate and exposure; neonicotinoids and fipronilBehavior research methods. Environ Sci Pollut Res Int 22:35-67

Botias C, David A, Horwood J, Abdul-Sada A, Nicholls E, Hill E, Goulson D (2015) Neonicotinoid residues in wildflowers, a potential route of chronic exposure for bees. Environ Sci Technol 49:12731-12740

Budge G, Garthwaite D, Crowe A, Boatman N, Delaplane K, Brown M, Thygesen H, Pietravalle S (2015) Evidence for pollinator cost 
and farming benefits of neonicotinoid seed coatings on oilseed rape. Sci Rep 5:12574

Bühl A (2012) SPSS 20: Einführung in die moderne Datenanalyse. Pearson Deutschland $\mathrm{GmbH}$, München, Germany

Charreton M, Decourtye A, Henry M, Rodet G, Sandoz JC, Charnet P, Collet C (2015) A locomotor deficit induced by sublethal doses of pyrethroid and neonicotinoid insecticides in the honeybee Apis mellifera. PLoS ONE 10:e144879

Cox-Foster DL, Conlan S, Holmes EC, Palacios G, Evans JD, Moran NA, Quan P-L, Briese T, Hornig M, Geiser DM (2007) A metagenomic survey of microbes in honey bee colony collapse disorder. Science 318:283-287

Cresswell JE (2011) A meta-analysis of experiments testing the effects of a neonicotinoid insecticide (imidacloprid) on honey bees. Ecotoxicology 20:149-157

Cresswell JE, Desneux N, vanEngelsdorp D (2012) Dietary traces of neonicotinoid pesticides as a cause of population declines in honey bees: an evaluation by Hill's epidemiological criteria. Pest Manag Sci 68:819-827

Cresswell JE, Robert FXL, Florance H, Smirnoff N (2014) Clearance of ingested neonicotinoid pesticide (imidacloprid) in honey bees (Apis mellifera) and bumblebees (Bombus terrestris). Pest Manag Sci 70:332-337

Cutler GC, Scott-Dupree CD (2007) Exposure to clothianidin seedtreated canola has no long-term impact on honey bees. J Econ Entomol 100:765-772

Cutler GC, Scott-Dupree CD, Sultan M, McFarlane AD, Brewer L (2014) A large-scale field study examining effects of exposure to clothianidin seed-treated canola on honey bee colony health, development, and overwintering success. PeerJ 2:e652

Di Prisco G, Cavaliere V, Annoscia D, Varricchio P, Caprio E, Nazzi F, Gargiulo G, Pennacchio F (2013) Neonicotinoid clothianidin adversely affects insect immunity and promotes replication of a viral pathogen in honey bees Proc Natl Acad Sci USA 110:18466-18471

Dietemann V, Nazzi F, Martin SJ, Anderson DL, Locke B, Delaplane KS, Wauquiez Q, Tannahill C, Frey E, Ziegelmann B, Rosenkranz P, Ellis JD (2013) Standard methods for varroa research. In: Dietemann V, Ellis J, Neumann P (eds) The COLOSS BEEBOOK, standard methods for Apis mellifera pest and pathogen research. International Bee Research Association, Cardiff, UK, vol II

Doublet V, Labarussias M, de Miranda JR, Moritz RF, Paxton RJ (2015) Bees under stress: sublethal doses of a neonicotinoid pesticide and pathogens interact to elevate honey bee mortality across the life cycle Environ Microbiol 17:969-983

EC (2013) Commission Implementing Regulation (EU) No 485/2013 of 24 May 2013 amending Implementing Regulation (EU) No $540 / 2011$, as regards the conditions of approval of the active substances clothianidin, thiamethoxam and imidacloprid, and prohibiting the use and sale of seeds treated with plant protection products containing those active substances. OJ139: 12-26

EFSA Panel on Plant Protection Products and their Residues (PPR) (2012) Scientific Opinion on the science behind the development of a risk assessment of Plant Protection Products on bees (Apis mellifera, Bombus spp. and solitary bees). EFSA J 10:2668

Elbert A, Haas M, Springer B, Thielert W, Nauen R (2008) Applied aspects of neonicotinoid uses in crop protection. Pest Manag Sci 64:1099-1105

European Food Safety Authority (efsa) (2013) Conclusion on the peer review of the pesticide risk assessment for bees for the active substance clothianidin. EFSA J 11:58

Fairbrother A, Purdy J, Anderson T, Fell R (2014) Risks of neonicotinoid insecticides to honeybees. Environ Toxicol Chem 33:719-731
Fischer J, Müller T, Spatz A-K, Greggers U, Gruenewald B, Menzel R (2014) Neonicotinoids interfere with specific components of navigation in honeybees. PLoS ONE 9:e91364

Forster R (2009) Bee poisoning caused by insecticidal seed treatment of maize in Germany in 2008. Jul-Kühn-Arch 423:126-131

Forster R, Giffard H, Heimbach U, Laporte J-M, Lückmann J, Nikolakis A, Pistorius J, Vergnet C (2012) ICPBR-Working Group Risks posed by dusts: overview of the area and recommendations. Jul-Kühn-Arch 437:191

Genersch E, Von Der Ohe W, Kaatz H, Schroeder A, Otten C, Büchler R, Berg S, Ritter W, Mühlen W, Gisder S (2010) The German bee monitoring project: a long term study to understand periodically high winter losses of honey bee colonies. Apidologie 41:332-352

Girolami V, Mazzon L, Squartini A, Mori N, Marzaro M, Di Bernardo A, Greatti M, Giorio C, Tapparo A (2009) Translocation of neonicotinoid insecticides from coated seeds to seedling guttation drops: a novel way of intoxication for bees. J Econ Entomol 102:1808-1815

Godfray HC, Blacquiere T, Field LM, Hails RS, Petrokofsky G, Potts SG, Raine NE, Vanbergen AJ, McLean AR (2014) A restatement of the natural science evidence base concerning neonicotinoid insecticides and insect pollinators. Proc Biol Sci 281: pii: 20140558

Guzmán-Novoa E, Eccles L, Calvete Y, Mcgowan J, Kelly PG, Correa-Benítez A (2010) Varroa destructor is the main culprit for the death and reduced populations of overwintered honey bee (Apis mellifera) colonies in Ontario, Canada. Apidologie 41:443-450

Hazardous Substances Data Bank HSDB (2005) Clothianidin Hazardous Substances Databank Number: 7281 National Library of Medicine (US), Bethesda (MD), accessed 15 November 2016

Henry M, Beguin M, Requier F, Rollin O, Odoux J-F, Aupinel P, Aptel J, Tchamitchian S, Decourtye A (2012) A common pesticide decreases foraging success and survival in honey bees. Science 336:348-350

Imdorf A, Buehlmann G, Gerig L, Kilchenmann V, Wille H (1987) A test of the method of estimation of brood areas and number of worker bees in free-flying colonies [Liebefeld method]. Apidologie 18:137-146

Krupke CH, Hunt GJ, Eitzer BD, Andino G, Given K (2012) Multiple routes of pesticide exposure for honey bees living near agricultural fields. PLoS ONE 7:e29268

Maienfisch P, Angst M, Brandl F, Fischer W, Hofer D, Kayser H, Kobel W, Rindlisbacher A, Senn R, Steinemann A (2001) Chemistry and biology of thiamethoxam: a second generation neonicotinoid. Pest Manag Sci 57:906-913

Main AR, Headley JV, Peru KM, Michel NL, Cessna AJ, Morrissey CA (2014) Widespread use and frequent detection of neonicotinoid insecticides in wetlands of Canada's Prairie Pothole Region. PLoS ONE 9:e92821

Nauen R, Ebbinghaus-Kintscher U, Salgado VL, Kaussmann M (2003) Thiamethoxam is a neonicotinoid precursor converted to clothianidin in insects and plants. Pestic Biochem Physiol 76:55-69

Neumann P, Carreck NL (2010) Honey bee colony losses. J Apic Res 49:1-6

Nikolakis A, Chapple A, Friessleben R, Neumann P, Schad T, Schmuck R, Schnier H-F, Schnorbach H-J, Schöning R, Maus C (2010) An effective risk management approach to prevent bee damage due to the emission of abraded seed treatment particles during sowing of seeds treated with bee toxic insecticides. JulKühn-Arch 423:132

Nikolakis A, Keppler J, Miles M, Schoening R (2015) Neonicotinoid seed treatment products-occurrence and relevance of guttation for honey bee colonies. Jul-Kühn-Arch 450:160 
OEPP/EPPO (2010) Guideline for the efficacy evaluation of plant protection products - Side effects on honeybees. Bulletin OEPP/ EPPO Bulletin 40

Pilling E, Campbell P, Coulson M, Ruddle N, Tornier I (2013) A fouryear field program investigating long-term effects of repeated exposure of honey bee colonies to flowering crops treated with thiamethoxam. PLoS ONE 8:e77193

Pistorius J, Bischoff G, Heimbach U, Stähler M (2010) Bee poisoning incidents in Germany in spring 2008 caused by abrasion of active substance from treated seeds during sowing of maize. Jul-KühnArch 423:118

Pistorius J, Brobyn T, Campbell P, Forster R, Lortsch J-A, Marolleau F, Maus C, Lückmann J, Suzuki H, Wallner K (2012) Assessment of risks to honey bees posed by guttation. Jul-Kühn-Arch 437:199

Pohorecka K, Skubida P, Miszczak A, Semkiw P, Sikorski P, Zagibajło K, Teper D, Kołtowski Z, Skubida M, Zdańska D (2012) Residues of neonicotinoid insecticides in bee collected plant materials from oilseed rape crops and their effect on bee colonies. J Apic Sci 56:115-134

Reetz JE, Zühlke S, Spiteller M, Wallner K (2011) Neonicotinoid insecticides translocated in guttated droplets of seed-treated maize and wheat: a threat to honeybees? Apidologie 42:596-606

Rolke D, Fuchs S, Grünewald B, Gao Z, Blenau W (2016a) Largescale monitoring of effects of clothianidin-dressed oilseed rape seeds on pollinating insects in Northern Germany: effects on honey bees (Apis mellifera). Ecotoxicology 25: 1648-1665

Rolke D, Persigehl M, Peters B, Sterk G, Blenau W (2016b) Largescale monitoring of effects of clothianidin-dressed oilseed rape seeds on pollinating insects in northern Germany: residues of clothianidin in pollen, nectar and honey. Ecotoxicology 25:1691-1701. https://doi.org/10.1007/s10646-016-1723-x

Rondeau G, Sanchez-Bayo F, Tennekes HA, Decourtye A, RamirezRomero R, Desneux N (2014) Delayed and time-cumulative toxicity of imidacloprid in bees, ants and termites. Sci Rep 4:5566

Rundlof M, Andersson GK, Bommarco R, Fries I, Hederstrom V, Herbertsson L, Jonsson O, Klatt BK, Pedersen TR, Yourstone J, Smith HG (2015) Seed coating with a neonicotinoid insecticide negatively affects wild bees. Nature 521:77-80

Sandrock C, Tanadini M, Tanadini LG, Fauser-Misslin A, Potts SG, Neumann P (2014) Impact of chronic neonicotinoid exposure on honey bee colony performance and queen supersedure. PLoS ONE 9:e103592

Schaafsma A, Limay-Rios V, Baute T, Smith J, Xue Y (2015) Neonicotinoid insecticide residues in surface water and soil associated with commercial maize (corn) fields in southwestern Ontario. PLoS ONE 10:e0118139

Schmuck R, Keppler J (2003) Clothianidin-Ecotoxicological profile and risk assessment. Bayer-Pflanzenschutz Bayer 56:26-58
Schmuck R, Lewis G (2016) Review of field and monitoring studies investigating the role of nitro-substituted neonicotinoid insecticides in the reported losses of honey bee colonies (Apis mellifera). Ecotoxicology 25:1617-1629

Schneider CW, Tautz J, Grünewald B, Fuchs S (2012) RFID tracking of sublethal effects of two neonicotinoid insecticides on the foraging behavior of Apis mellifera. PLoS ONE 7:e30023

Schoening R (2001) Modification M001 of the Residue Analytical Method 00554 for the Determination of Residues of TI 435, TZNG and TZMU Metabolite in Nectar (Honey) and Pollen by HPLC with ElectrosprayMS/MS-detection, September 2001. Bayer CropScience Document

Siede R, König M, Büchler R, Failing K, Thiel H-J (2008) A real-time PCR based survey on acute bee paralysis virus in German bee colonies. Apidologie 39:650-661

Simon-Delso N, Amaral-Rogers V, Belzunces LP, Bonmatin J-M, Chagnon M, Downs C, Furlan L, Gibbons DW, Giorio C, Girolami V (2015) Systemic insecticides (neonicotinoids and fipronil): trends, uses, mode of action and metabolites. Environ Sci Pollut Res 22:5-34

Tapparo A, Giorio C, Marzaro M, Marton D, Soldà L, Girolami V (2011) Rapid analysis of neonicotinoid insecticides in guttation drops of corn seedlings obtained from coated seeds. J Environ Monit 13:1564-1568

Thompson HM (2010) Risk assessment for honey bees and pesticides -recent developments and 'new issues'. Pest Manag Sci 66:1157-1162

U.S. Environmental Protection Agency (EPA) (2000) Assigning values to non-detected/non-quantified pesticide residues in human health food exposure assessments.

U.S. Environmental Protection Agency (EPA) (2006) Data quality assessment: statistical methods for practitioners. EPA/240/B-06/ 003 [Cited 2015 October 12]

Uneme H (2011) Chemistry of Clothianidin and related compounds. Agric Food Chem 59:2932-2937

Williamson SM, Willis SJ, Wright GA (2014) Exposure to neonicotinoids influences the motor function of adult worker honeybees. Ecotoxicology 23:1409-1418

Woodcock BA, Bullock JM, Shore RF, Heard MS, Pereira MG, Redhead J, Ridding L, Dean H, Sleep D, Henrys P, Peyton J, Hulmes S, Hulmes L, Sárospataki M, Saure C, Edwards M, Genersch E, Knäbe S, Pywell RF (2017) Country-specific effects of neonicotinoid pesticides on honey bees and wild bees. Science 356:1393-1395

Xu T, Dyer DG, McConnell LL, Bondarenko S, Allen R, Heinemann O (2016) Clothianidin in agricultural soils and uptake into corn pollen and canola nectar after multiyear seed treatment applications. Environ Toxicol Chem 35:311-321 